DOI: https://doi.org/10.32345/2664-4738.3-4.2019.01

UDC: 616.833-003.93L616.8-091.8+616.833-009.54)

\title{
LONG-TERM OUTCOMES OF RAT SCIATIC NERVE INJURY AND ITS GRAFTING WITH SILICON WIRES-BASED CONDUIT: DISTAL NERVE STUMP HISTOLOGY AND ELECTROMYOGRAPHY RESULTS
}

\author{
Likhodiievskyi $\boldsymbol{V}$. (https://orcid.org/0000-0002-7596-1207) \\ Korsak $\boldsymbol{A}$. (https://orcid.org/0000-0003-2723-2664) \\ Skopets D. (https://orcid.org/0000-0002-8390-427x) \\ Olefir S. (https://orcid.org/0000-0001-5527-842x) \\ Chukhrai S. (https://orcid.org/0000-0001-7431-7375) \\ Shamalo S. (https://orcid.org/0000-0003-1809-1476) \\ Chaikovsky Yu. (https://orcid.org/0000-0002-8821-8930) \\ Bogomolets National Medical University, Kyiv, Ukraine \\ Legebrill@gmail.com
}

\begin{abstract}
Relevance. The investigations on trauma epidemiology have shown that both combat- and noncombat-related extremity injuries are often accompanied by nerve injuries. These injuries disproportionately affect young healthy civilians and military officers and has a devastating impact on a patients' quality of life.

Severe nerve injuries, such as nerve trunk injury in continuity (Sunderland 5), that cannot be treated by neurorraphy without tension, require use of nerve gap bridging strategies with different materials and techniques.

Objective. This study was aimed to evaluate any positive or negative impact of implanted silicon wires on the quality of nerve fibers at distal nerve stump.

Materials and Methods. An experiment was performed on 40 male Whistar rats 2-4 month that were divided to the next groups:

$\mathrm{I},(\mathrm{n}=10)$ sham-operated, only surgical access to sciatic nerve was performed.

II $(\mathrm{n}=10)$ with $10 \mathrm{~mm}$ sciatic nerve gap that was bridged with autoneurografting.

III $(\mathrm{n}=10)$ with $10 \mathrm{~mm}$ nerve gap that was bridged with allogenic decell aorta filled with $4 \%$ carboxymethylcellulose hydrogel.

IV $(n=10)$ with $10 \mathrm{~mm}$ nerve gap that was bridged with allogenic decell aorta filled with $4 \%$ carboxymethylcellulose hydrogel and aligned p-type silicon microvires.

Decellularization of allogenic aortas was performed by freeze-thaw cycles.

Silicon whiskers were fabricated by Vapor-Liquid-Solid (VLS) method in a cold wall Catalytic Chemical Vapor Deposition (CatCVD) chamber, pre-cleaned with hydrofluoric acid and sterilized via $180 * \mathrm{C}$ dry heat.

12 weeks after surgery under general anesthesia all rats underwent invasive needle electroneurpmyography with proximal nerve stump stimulation and registration from gastrocnemius muscle. Myograms were recorded and compared by the shape of M-reflex and its amplitude.

After myography rats were euthanized under thiopentone overdosage and distal stumps of injured sciatic nerves were harvested for light microscopy.

Sciatic nerve transverse slices were stained with nitric silver by modified Bielschowsky method Nerve fiber diameter, axon diameter, myelin sheath thickness and axon-to-nerve fiber diameter ratio (g-ratio) were measured.

Results. Performed analysis showed that rats from II and IV groups demonstrated the best quality of nerve fibers in distal nerve stump. That was evidenced by bigger nerve fibers diameter in rats from autologous nerve grafting group and aorta with gel and wires grafting group in comparison with aorta with gel grafting group. Rats from IV demonstrated higher voltage and lower latency of Mreflexes during electromyography.

Conclusions. It can be concluded about the possible pro-regenerative impact of implanted silicon wires that was evidenced by better nerve fibers quality at distal nerve stump.
\end{abstract}

Key words: nerve injury, peripheral nerve grafting, silicon wires

Relevance. In accordance with last investigations on trauma epidemiology both combat- and noncombatrelated extremity injuries are often accompanied with nerve injuries $[1,2,3]$.

Severe nerve trunk injuries were often observed among military personnel who with ballistic and blast soft tissue injuries that are more prevalent during ongoing armed conflicts [4].

These injuries disproportionately affect young healthy civilians and military officers who are most at risk of traumatic injuries [2] and has a devastating impact on a patients' quality of life [5]. 
Severe nerve injuries, such as nerve trunk injury in continuity (Sunderland 5), that cannot be treated by neurorraphy without tension, require use of nerve gap bridging strategies [6]. Autoneurografting is still considered as a gold-standard method [6] but existed disadvantages and shortcomings of this strategy like fascicular structure mismatch and donor site denervation form huge request for the development of new materials and ways of nerve grafting [7].

The aim of nerve grafting is not only to restore anatomical integrity of the nerve trunk but to provide successful axonal outgrow and organ re-innervation.

The functional outcomes, especially motor function regain can be considered as primary endpoint. Keeping in mind the importance of early events directly at nerve injury site [8] for satisfactory recovery results the secondary endpoints of nerve regeneration such as nerve fibers morphometrics and its functional abilities also must be estimated [9].

Nowadays, hollow conduits filled with hydrogels and/or oriented filaments are considered as suitable alternative to autoneurografting by creation of friendly microenvironment for nerve fibers [10]. Exact this property of nerve grafts has been proclaimed as essential for successful nerve regeneration [11]. Recent advances in hollow conduit fabrication were resulted in successful introduction of some commercially available conduits to clinical practice [12]. But such artificial conduits still are not capable to bridge critical nerve defects in humans.

The last research papers renewed interest in implantation of intraluminal guides with electroconductive properties such as polyimide [13, 14]. Both with this, semiconductor silicone seems to be perspective as for integral micro schemes fabrication and for construction of implanted intraluminal electrodes as part of most perspective regenerative tubular implants for peripheral nerve interfacing $[15,16,17]$.

We also consider 12 weeks after surgery as longterm point and perform analysis exact at that term keeping in mind average speed of nerve fibers outgrowth and prognosed end of of axonal and myelination phases till the end of 12 week. At this term the functional results of regeneration reach plateau what is considered with many researchers as stable long-term outcomes $[9,18]$.

Nevertheless, the number of axons that grow through injury site and reached distal nerve stump was considered as direct quality indicator of successful regeneration $[19,20]$, last research papers are highlighting that quality (diameter, myelin shell thickness, shape) of new-formed nerve fibers can be so important as their quantity [21].

Peripheral nerve morphometry cannot be considered anymore as a single-standing quality indicator, especially of long-term outcomes [9], that's why electrophysiological tests also must be performed.
Objective. This study was aimed to evaluate any positive or negative impact of implanted silicon wires on quality of nerve fibers at distal nerve stump.

\section{MATERIALS AND METHODS}

An experiment was performed on 40 male Whistar rats 2-4 month, housed under natural light-dark cycle, and free access to water and food.

All manipulations were performed in accordance to "Rules of work using experimental animals", approved by order of the Ministry of Health of Ukraine and Directive 2010/63/EU (on the protection of animals used for scientific purposes) of the European Parliament and Council of Europe. The research was approved by the Committee on bioethics expertise and scientific research ethics at Bogomolets National Medical University, Minutes № 12, 30 December 2015.

We perform all surgical interventions under intraperitoneal thiopentone anesthesia $(40 \mathrm{mg} / \mathrm{kg})$ [22]

All rats were randomly divided to next groups:

I $(\mathrm{n}=10)$ sham-operated, only surgical access to sciatic nerve was performed.

II $(\mathrm{n}=10)$ autoneurografting, right sciatic nerve was exposed in mid tigh, $10 \mathrm{~mm}$ of nerve trunk was removed and re-sutured to formed nerve gap with 4 epineural stitches to each stump (10/0 Daflon, B.Braun, Germany) [6].

III $(n=10)$ allogenic aorta grafting, after sciatic nerve exposure and $10 \mathrm{~mm}$ of nerve trunk excision, interneural gap was filled by allogenic decell aorta filled with $4 \%$ carboxymethylcellulose hydrogel. The conduit was sutured with 2 n-like stitches to each stump (10/0 Daflon, B.Braun, Germany) [6].

Decellularization of allogenic aortas was performed by freeze-thaw cycles.

IV $(n=10)$ silicon wires grafting, after sciatic nerve exposure and $10 \mathrm{~mm}$ of nerve trunk excision, interneural gap was filled by allogenic decell aorta filled with $4 \%$ carboxymethylcellulose hydrogel and longitudinally oriented silicon wires (p-type, Boronligated). Conduit was sutured to nerve stumps in the same way as in III group.

Silicon whiskers were fabricated by the VaporLiquid-Solid (VLS) method in a cold wall Catalytic Chemical Vapor Deposition (Cat-CVD) chamber [23].

After fabrication silicon wires were pre-cleaned with isopropyl alcohol, deionized water and treated with hydrofluoric acid to remove the surface oxide layer. After surface preparation wires were cleaned with deionized water and sterilized via $180 * \mathrm{C}$ dry heat [24].

12 weeks after surgery under general anesthesia all rats underwent invasive needle electroneuromyography by myographic complex (M-test 4, DX-systems, Ukraine) with proximal nerve stump stimulation $(1 \mathrm{~Hz}$, 1-2,5 mA). Myograms were recorded at gastrocnemius 
muscle and compared by the shape of M-reflex and its amplitude.

After registration rats were euthanized under thiopentone overdosage and distal stumps of injured sciatic nerves were harvested for light microscopy.

Sciatic nerve transverse formalin-fixed paraffinembedded (FFPE) $10 \mathrm{~mm}$ thick slices were stained with nitric silver by the modified Bielschowsky method [25].

Obtained sections were examined with an Olympus BX51 light microscope with an attached Olympus zoom 4040 digital camera (Olympus, Japan).

At sciatic nerve transverse sections nerve fiber diameter, axon diameter, myelin sheath thickness and axon-to-nerve fiber diameter ratio (g-ratio) were measured.

All digital photos were processed and all measures were performed using ImageJ ver 1.50 software for biomedical images analysis (freeware, NIH, USA).

Obtained statistical data were analyzed using IBM SPSS Statistics Base v.22 SPSS Statistics Base v.22 software (IBM, USA, Bogomolets National Medical University academic license \#128 since 01.08.2016).

Distribution of obtained data was analyzed using D'Augostino\&Pearson test, differences between groups were estimated by using the Kruskal-Wallis test with post-hoc Mann-Whitney test. Data were presented as Median; 95\% CI ofMedian. Differences were considered at significance level $\mathrm{p}<0.01$.

\section{RESULTS AND DISCUSSION}

12 weeks after surgery all animals demonstrated no signs of surgical site infection and injured sciatic nerve can be subdivided to 5 parts - proximal and distal nerve stumps, proximal and distal nerve-to-graft sites and graft site.
At 12 week after sham operation nerve was composed of many round-shaped nerve fibers with thick myelin shells and round-shaped axons.

12 weeks after surgery rats from II group (autoneurografting) demonstrated the presence of thin and thick new-formed oval-shaped nerve fibers with thick myelin shells and oval axons. Nerve fiber diameter, axon diameter, myelin sheath thickness, mwave amplitude and latency were shown in Table 1.

There was no difference in nerve fiber diameter between II (Autoneurografting) and I (Sham-operated) groups $(p=0,3331)$. Rats from this group in comparison with sham-operated rats demonstrated lower axon diameter $(p=0,0026)$, thicker myelin sheath $(p<0,0001)$. Electromyography also registered lower m-wave amplitude $(\mathrm{p}<0,0001)$ and higher latency $(\mathrm{p}<0,0001)$, Figure 1, B.

Rats from III group (aorta+gel grafting) 12 weeks after surgery demonstrated presence of round-shaped thin and thick nerve fibers with thin myelin shells and round axons. Nerve fiber diameter, axon diameter, myelin sheath thickness, m-wave amplitude and latency were shown in Table 1.

There was substantial difference in nerve fiber diameter between III (Aorta+gel grafting) and I (Shamoperated) groups $(\mathrm{p}<0,0001)$. Rats from this group in comparison with sham-operated rats also demonstrated lower axon diameter $(\mathrm{p}<0,0001)$, thinner myelin sheath $(\mathrm{p}<0,0001)$. Electromyography registered lower $\mathrm{m}$ wave amplitude $(\mathrm{p}<0,0001)$ and higher latency $(\mathrm{p}<0,0001)$, Figure 1, C.

Rats from III experimental group (Aorta+gel grafting) in comparison with II (Autoneurografting) group also demonstrated lower nerve fiber diameter $(p<0,0001)$ but showed no difference in axon diameter $(p=0,7334)$. Myelin sheath thickness was lower

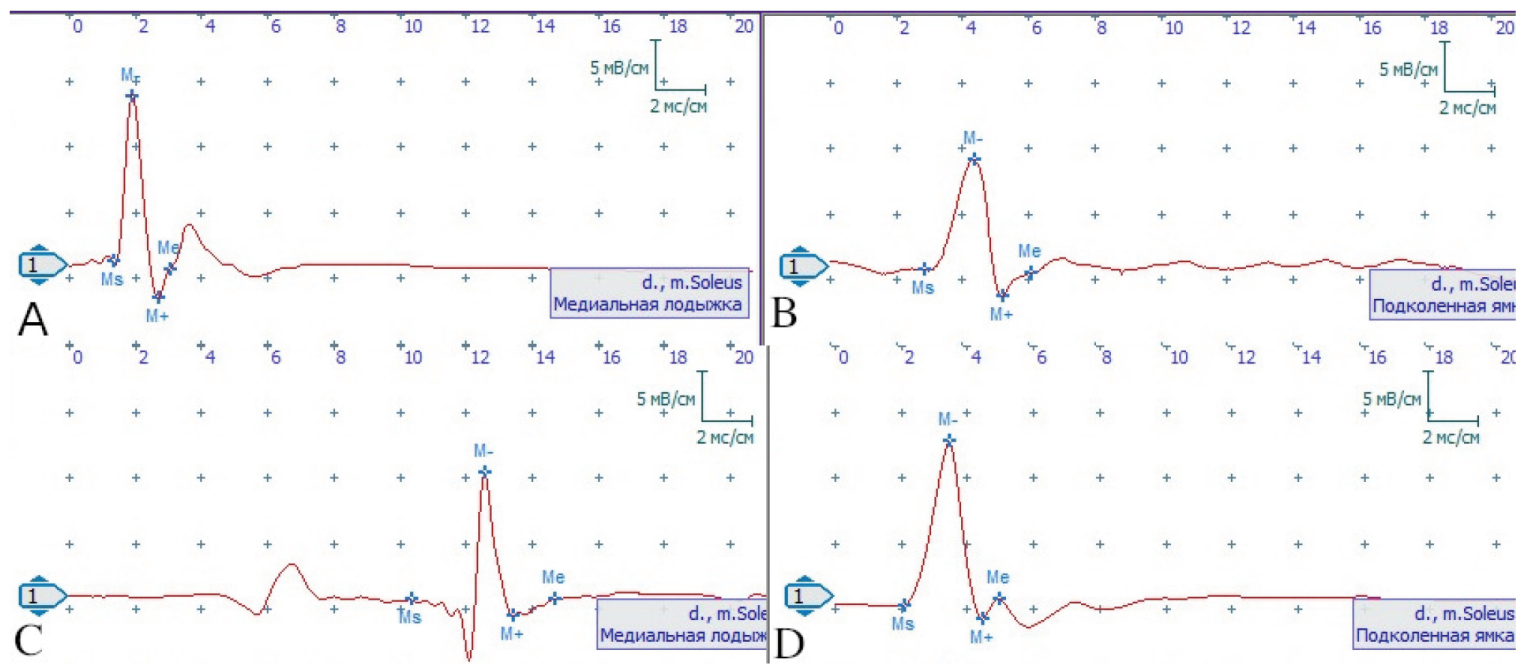

Figure 1. EMG results. A - Sham-operated; B - Autoneurografting; C - Aorta with gel grafting; D - Aorta with gel and silicone wires grafting 
$(\mathrm{p}<0,0001)$ and EMG showed that $\mathrm{m}$-wave amplitude was lower, but without significant difference $(p=0,0640)$, both with this latency was substantially increased $(\mathrm{p}<0,0001)$.

12 weeks after injury rats from IV group (silicon wires grafting) had distal nerve stump with huge amount of round-shaped moderately myelinated new nerve fibers. Nerve fiber diameter, axon diameter, myelin sheath thickness, m-wave amplitude and latency were shown in Table 1.

There was no substantial difference in nerve fiber diameter between IV (Aorta+gel+silicone wires grafting) and I (Sham-operated) groups $(p=0,4954)$. Rats from this group in comparison with sham-operated rats also demonstrated lower axon diameter without significant difference $(\mathrm{p}=0,0690)$, and no differences in myelin sheath thickness

Rats from IV experimental group (Aorta+gel+silicone wires grafting grafting) in comparison with II (Autoneurografting) group demonstrated no differences in nerve fiber diameter ( $\mathrm{p}=0,1258)$, no difference in axon diameter $(p=0,1878)$ but lower myelin sheath thickness $(p=0,0005)$. EMG showed that $\mathrm{m}$-wave amplitude was significantly higher $(\mathrm{p}<0,0001)$, both with this, there was no difference in latency $(p=0,0440)$ Figure $1, D$.

In comparison with II (Autoneurografting) group rats from IV experimental group (Aorta+gel+silicone wires grafting grafting) demonstrated larger nerve fiber diameter $(p=0,0007)$ but no difference in axon diameter $(p=0,0906)$ and thicker myelin sheath $(p=0,0003)$. EMG showed that m-wave amplitude was significantly higher $(p<0,0001)$, and latency was shorter $(p<0,0001)$.

Performed analysis showed that rats from II and IV groups demonstrated the pump quality of nerve fibers in distal nerve stump. That was evidenced by bigger nerve fibers diameter in rats from autologous grafting group and aorta with gel and wires grafting group in comparison with aorta+gel grafting group.

The obtained data are supported by Hoffman, that showed strong positive correlation between regenerated axons diameter and functional outcomes. Fiber and axon diameter are the classical parameter for nerve type identification since they have proven to be the main determinant of conduction velocity [26]

It also was revealed that rats from II and IV groups had thicker myelin shell than rats from III group.

Table 1

Results of statistical comparison of defined parameters. Data presented as Median, $95 \%$ CI of Median

\begin{tabular}{|c|c|c|c|c|c|c|}
\hline $\begin{array}{c}\text { Groups } \\
\text { and parameters }\end{array}$ & $\begin{array}{c}\text { I group } \\
\text { (Sham-operated) }\end{array}$ & $\begin{array}{c}\text { II } \\
\text { (Autologous } \\
\text { nerve grafting) }\end{array}$ & $\begin{array}{c}\text { III } \\
\text { (Allogenic } \\
\text { aorta+gel } \\
\text { grafting) }\end{array}$ & $\begin{array}{c}\text { IV } \\
\text { (Allogenic } \\
\text { aorta+gel_silicon } \\
\text { wires grafting) }\end{array}$ & & sts \\
\hline \multirow{4}{*}{$\begin{array}{l}\text { Nerve fiber } \\
\text { diameter, } \mu \mathrm{m},\end{array}$} & \multirow{4}{*}{$\begin{array}{c}7,045 \\
5,864-7,519\end{array}$} & $\begin{array}{c}6,817 \\
6,397-8,022 \\
\end{array}$ & $\begin{array}{c}5,113 \\
4,711-5,764\end{array}$ & $\begin{array}{c}6,343 \\
5,782-6,642 \\
\end{array}$ & $\mathrm{P}<0,0001$ & K-W test \\
\hline & & $\mathrm{P}=0,3331$ & $\mathrm{P}<0,0001$ & $\mathrm{P}=0,4954$ & \multicolumn{2}{|c|}{$\begin{array}{l}\text { M-W test } \\
\text { vs Sham-operated (I) }\end{array}$} \\
\hline & & - & $\mathrm{P}<0,0001$ & $\mathrm{P}=0,1258$ & \multicolumn{2}{|c|}{ M-W test vs Autologous graft (II) } \\
\hline & & - & - & $\mathrm{P}=0,0007$ & \multicolumn{2}{|c|}{ M-W test vs aorta+gel graft (III) } \\
\hline \multirow{4}{*}{$\begin{array}{l}\text { Axon diameter, } \\
\mu \mathrm{m},\end{array}$} & \multirow{4}{*}{$\begin{array}{c}3,552 \\
3,266-4,221\end{array}$} & $\begin{array}{c}2,598 \\
2,170-3,452\end{array}$ & $\begin{array}{c}2,594 \\
2,292-2,784\end{array}$ & $\begin{array}{c}3,348 \\
2,504-3,847\end{array}$ & $\mathrm{P}=0,0006$ & $\mathrm{~K}-\mathrm{W}$ test \\
\hline & & $\mathrm{P}=0,0026$ & $\mathrm{P}<0,0001$ & $\mathrm{P}=0,0690$ & \multicolumn{2}{|c|}{$\begin{array}{l}\text { M-W test } \\
\text { vs Sham-operated (I) } \\
\end{array}$} \\
\hline & & - & $\mathrm{P}=0,7334$ & $\mathrm{P}=0,1878$ & \multicolumn{2}{|c|}{ M-W test vs Autologous graft (II) } \\
\hline & & - & - & $\mathrm{P}=0,0906$ & \multicolumn{2}{|c|}{ M-W test vs aorta+gel graft (III) } \\
\hline \multirow{4}{*}{$\begin{array}{l}\text { Myelin } \\
\text { thickness, } \mu \mathrm{m}\end{array}$} & \multirow{4}{*}{$\begin{array}{c}1,417 \\
1,363-1,643\end{array}$} & $\begin{array}{c}2,018 \\
1,920-2,331 \\
\end{array}$ & $\begin{array}{c}1,288 \\
1,209-1,452 \\
\end{array}$ & $\begin{array}{c}1,626 \\
1,387-1,823 \\
\end{array}$ & $\mathrm{P}<0,0001$ & K-W test \\
\hline & & $\mathrm{P}<0,0001$ & $\mathrm{P}<0,0001$ & $\mathrm{P}=0,0701$ & \multicolumn{2}{|c|}{\begin{tabular}{|l|} 
M-W test \\
vs Sham-operated (I) \\
\end{tabular}} \\
\hline & & - & $\mathrm{P}<0,0001$ & $\mathrm{P}=0,0005$ & \multicolumn{2}{|c|}{ M-W test vs Autologous graft (II) } \\
\hline & & - & - & $\mathrm{P}=0,0003$ & \multicolumn{2}{|c|}{ M-W test vs aorta+gel graft (III) } \\
\hline \multirow{4}{*}{$\begin{array}{l}\text { M-reflex } \\
\text { amplitude, mV }\end{array}$} & \multirow{4}{*}{$\begin{array}{c}11,73 ; \\
9,580-12,67\end{array}$} & $\begin{array}{c}6,360 \\
2,350-8,060\end{array}$ & $\begin{array}{c}2,995 \\
1,890-4,120\end{array}$ & $\begin{array}{c}11,83 \\
8,890-12,28\end{array}$ & $\mathrm{P}<0,0001$ & $\mathrm{~K}-\mathrm{W}$ test \\
\hline & & $\mathrm{P}<0,0001$ & $\mathrm{P}<0,0001$ & $\mathrm{P}=0,7381$ & \multicolumn{2}{|c|}{$\begin{array}{l}\text { M-W test } \\
\text { vs Sham-operated (I) }\end{array}$} \\
\hline & & - & $\mathrm{P}=0,0640$ & $\mathrm{P}<0,0001$ & \multirow{2}{*}{\multicolumn{2}{|c|}{$\begin{array}{l}\text { M-W test vs Autologous graft (II) } \\
\text { M-W test vs aorta+gel graft (III) }\end{array}$}} \\
\hline & & - & - & $\mathrm{P}<0,0001$ & & \\
\hline \multirow{4}{*}{$\begin{array}{l}\text { M-reflex } \\
\text { latency, mS, }\end{array}$} & \multirow{4}{*}{$\begin{array}{c}1,0 \\
1,0-1,3\end{array}$} & $\begin{array}{c}2,20 \\
2,100-2,200\end{array}$ & $\begin{array}{c}11,98 \\
11,20-12,35 \\
\end{array}$ & $\begin{array}{c}2,100 \\
2,050-2,100\end{array}$ & $\mathrm{P}<0,0001$ & $\mathrm{~K}-\mathrm{W}$ test \\
\hline & & $\mathrm{P}<0,0001$ & $\mathrm{P}<0,0001$ & $\mathrm{P}<0,0001$ & \multicolumn{2}{|c|}{$\begin{array}{l}\text { M-W test } \\
\text { vs Sham-operated (I) }\end{array}$} \\
\hline & & - & $\mathrm{P}<0,0001$ & $\mathrm{P}=0,0440$ & \multicolumn{2}{|c|}{$\begin{array}{l}\text { M-W test vs Autologous graft (II) } \\
\text { M-W test v arta+ol oraft (III) }\end{array}$} \\
\hline & & - & - & $\mathrm{P}<0,0001$ & \multicolumn{2}{|c|}{ M-W test vs aorta+gel graft (III) } \\
\hline
\end{tabular}


Bigger myelin shell thickness at distal nerve stump in rats from II group can be explained with myelin maturation and its incomplete compactization as it was showed by Sanders [27].

Both with this, rats from II group got smaller in diameter axons comparatively to the rats from I and IV group that can be considered as sign of excessive sprouting [9].

Revealed changed EMG m-waves are typical for nerves after injury and regeneration [18], both with this amplitude latency of m-wave strongly correlates with quality of new-formed nerve fibers [18].

Rats from II and IV groups demonstrated shape of EMG m-reflex that was close to sham-operated group that indicates to more complete regeneration with reestablished connections to larger amount of motor units $[18,28]$.

Obtained histological data are supported by results of EMG: decreased amplitude and increased latency of m-rexlex in rats from III group can be considered as relatively unsatisfactory results and indicates to impaired or delayed nerve regeneration. In contrast to this, rats from II and IV groups had m-reflex amplitude that reached to this indicator in sham-operated rats and can be considered as sign of relatively successful regeneration and better nerve fibers quality $[18,29$, 30]. Rats from all experimental groups demonstrated prolonged latency of m-wave on EMG in comparison with sham-operated rats, but we revealed less pronounced prolongation of $\mathrm{m}$-wave latency in rats from II and IV groups in contrast with m-wave latency at III group that shows that rats from II and IV groups had better quality of new-formed nerve fibers.

The prospects of future research are conducting of neurophysiological experiments on acute and chronic silicon wires implantation with stimulation and recording of action potentials from implanted electrodes.

\section{CONCLUSIONS}

It can be concluded about possible pro-regenerative impact of implanted silicon wires that was evidenced by better nerve fibers quality at distal nerve stump, restoration of shape, amplitude and latency of EMG mwave.

Acknowledgments: We want to express our gratitude to the staff of the Department of Ion Beam Engineering at V.Y. Lashkaryov Institute of Semiconductor Physics for silicon wires fabrication and processing

Conflict of interests. Authors declare that there is no conflict of interests.

Sources of funding This work was supported by State Fund for Fundamental Research of Ukraine (grant number F64/25 2015-2016).

\section{REFERENCES}

1. Rivera J., Glebus G., Cho M. Disability following combat-sustained nerve injury of the upper limb // The Bone \& Joint Journal. 2014; 96-B (2): 254-8. https:// doi.org/10.1302 / 0301-620X.96B2.31798

2. Taylor C., Braza D., Rice J., Dillingham T. The Incidence of Peripheral Nerve Injury in Extremity Trauma // American Journal of Physical Medicine \& Rehabilitation. 2008; 87 (5): 381-5. https://doi.org/ 10.1097 / PHM.0b013e31815e6370

3. Saadat S., Eslami V., Rahimi-movaghar V. The incidence of peripheral nerve injury in trauma patients in Iran // Turkish Journal of Trauma and Emergency Surgery. 2011; 17 (6): 539-44. https://doi.org/10.5505 / tjtes.2011.75735

4. Shin E., Sabino J., Nanos G., Valerio I. Ballistic Trauma: Lessons Learned from Iraq and Afghanistan / / Seminars in Plastic Surgery. 2015; 29 (1): 10-9. https://doi.org/10.1055 / s-0035-1544173

5. Vasileiadis A. Bridging of Peripheral Nerve Defects by Autologous Nerve Grafting Personal Experience // MOJ Orthopedics \& Rheumatology. 2016; 5 (3): 1-16. https://doi.org/10.15406/mojor.2016.05.00183

6. Hunt T., Wiesel S. Operative techniques in hand, wrist, and forearm surgery. Philadelphia: Lippincott Williams \& Wilkins; 2011. ISBN-13: 9781451102550 URL: https://www.amazon.com/ Operative-Techniques-Wrist-Forearm-Surgery-ebook/ dp/B007IVBNZU

7. Pi H., Gao Y., Wang Y., Kong D., Qu B., Su X. et al. Nerve autografts and tissue-engineered materials for the repair of peripheral nerve injuries: a 5-year bibliometric analysis // Neural Regeneration Research. 2015; 10 (6): 1003-8. https://doi.org/10.4103/16735374.158369 .

8. Geraschenko S., Deltsova O., Kolomiitsev A., Chaikovsky Y. [Periferiynyi nerv (neiro-sudynno-desmalni vzaiemovidnoshennya v normi i pry patologii)] / ISBN 966-673-069-3. 1st ed. Ternopil: Ukrmedknyha; 2005. [in Ukrainian] URL: http://www.irbisnbuv.gov.ua/cgi-bin/irbis_nbuv/cgiirbis_64.exe? Z 21 I D = \& I 21 D B N = R E F \& P $21 \mathrm{D} \mathrm{B} \mathrm{N=}$ $\mathrm{REF} \& \mathrm{~S} 21 \mathrm{STN}=1 \& \mathrm{~S} 21 \mathrm{REF}=10 \& \mathrm{~S} 21 \mathrm{FMT}=$ fullwebr\&C21COM=S\&S21CNR $=20 \& S 21 \mathrm{P} 01=$ 0\&S21P02 $=0 \& \mathrm{~S} 21 \mathrm{P} 03=\mathrm{A}=\& \mathrm{~S} 21 \mathrm{COLORTERMS}=$ $1 \& \mathrm{~S} 21 \mathrm{~S}$ T R $=\%$ D $0 \% 94 \%$ D $1 \% 94 \%$ D $0 \%$ BB\%D $1 \% 8 \mathrm{C} \% \mathrm{D} 1 \% 86 \% \mathrm{D} 0 \% \mathrm{BE} \% \mathrm{D} 0 \% \mathrm{~B} 2 \% \mathrm{D} 0 \%$ B0\%20\%D0\%9E\$

9. Raimondo S., Fornaro M., Di Scipio F., Ronchi G., Giacobini Robecchi M, Geuna S. Chapter 5 Methods and Protocols in Peripheral Nerve Regeneration Experimental Research // International Review of Neurobiology. 2009; 87: 81-103. https://doi.org/10.1016/ S0074-7742 (09) 87005-0.

10. Chiono V., Tonda Turo C., Ciardelli G. Chapter 9 Artificial Scaffolds for Peripheral Nerve Reconstruction // International Review of Neurobiology. 2009; 87:173-98. https://doi.org/10.1016 / S00747742 (09) 87009-8. 
11. Dahlin L., Johansson F., Lindwall C., Kanje M. Chapter 28 Future Perspective in Peripheral Nerve Reconstruction // International Review of Neurobiology. 2009; 87: 507-30. https://doi.org/ 10.1016 / S0074-7742 (09) 87028-1

12. Dietzmeyer N., Fцrthmann M., Leonhard J., Helmecke O., Brandenberger C., Freier T. et al. TwoChambered Chitosan Nerve Guides With Increased Bendability Support Recovery of Skilled Forelimb Reaching Similar to Autologous Nerve Grafts in the Rat $10 \mathrm{~mm}$ Median Nerve Injury and Repair Model // Frontiers in Cellular Neuroscience. 2019; 13: 149. https://doi.org/10.3389 / fncel.2019.00149.

13. Wang S., Cai L. Polymers for Fabricating Nerve Conduits // International Journal of Polymer Science. 2010; 2010: Article ID 138686, 1-20. http:// dx.doi.org/10.1155/2010/138686

14. Ordonez J., Boehler C., Schuettler M., Stieglitz T. Improved polyimide thin-film electrodes for neural implants // Annual International Conference of the IEEE Engineering in Medicine and Biology Society. 2012; 2012: 5134-7. https://doi.org/10.1109/ EMBC.2012.6347149.

15. Singh A., Shiekh P., Das M., Sеррдlд J., Kumar A. Aligned Chitosan-Gelatin Cryogel-Filled Polyurethane Nerve Guidance Channel for Neural Tissue Engineering: Fabrication, Characterization, and In Vitro Evaluation // Biomacromolecules. 2019; 20 (2): 662-73. https://doi.org/10.1021/ acs.biomac.8b01308.

16. Yu W, Zhao W, Zhu C, Zhang X, Ye D, Zhang W et al. Sciatic nerve regeneration in rats by a promising electrospun collagen/poly(e-caprolactone) nerve conduit with tailored degradation rate // BMC Neuroscience. 2011; 12 (1): 68. https://doi.org/ 10.1186 / 1471-2202-12-68.

17. Suzuki K., Kawauchi A., Nakamura T., Itoi S., Ito T., So J. et al. Histologic and Electrophysiological Study of Nerve Regeneration Using a Polyglycolic Acidcollagen Nerve Conduit Filled With Collagen Sponge in Canine Model // Urology. 2009; 74 (4): 958-63. https://doi.org/10.1016 / j.urology.2009.02.057.

18. Navarro X., Udina E. Chapter 6. Methods and Protocols in Peripheral Nerve Regeneration Experimental Research // International Review of Neurobiology. 2009; 87:105-126. https://doi.org/ 10.1016 / S0074-7742 (09) 87006-2.

19. Alvites R., Rita Caseiro A., Santos Pedrosa S., Vieira Branquinho M., Ronchi G., Geuna S. et al. Peripheral nerve injury and axonotmesis: State of the art and recent advances // Cogent Medicine. 2018; 5 (1): 1-22. URL: https://www.tandfonline.com/doi/full/10.1080/ 2331205X.2018.1466404
20. Mills S. Histology for pathologists. Philadelphia; 2007. ISBN: 1496398947

21. Deumens R., Bozkurt A., Meek M., Marcus M., Joosten E., Weis J. et al. Repairing injured peripheral nerves: Bridging the gap // Progress in Neurobiology. 2010; 92 (3): 245-76. https://doi.org/10.1016/ j.pneurobio.2010.10.002.

22. Flecknell P. Laboratory Animal Anaesthesia Ed. 4. Academic Press; 2015. ISBN 978-0-12-800036-6

23. Klimovskaya A., Kalashnyk Y., Voroshchenko A., Oberemok O., Pedchenko Y., Lytvyn P. Growth of silicon self-assembled nanowires by using gold-enhanced CVD technology // Semiconductor Physics, Quantum Electronics and Optoelectronics. 2018; 21 (3): 282-7. https://doi.org/10.15407/spqeo21.03.282 URL: https:// www.researchgate.net/publication/328814565 Growth_of_silicon_self-assembled ${ }_{-}^{-}$ nanowires_by_using_gold-enhanced_CVD_technology

24. Reinhardt K., Kern W. Handbook of silicon wafer cleaning technology. Norwich, NY: William Andrew; 2008. ISBN: 9780815517733

25. Kolomiitsev A. K., Chaikovsky Yu. B., Tereschenko T.L. Fast method of peripheral nervous system nitric silver impregnation suitable for celloidine and parafine slices // Archives of anatomy, histology and embryology. 1981; 8: 93-6. [in Russian]

26. Hoffman P. Review: The Synthesis, Axonal Transport, and Phosphorylation of Neurofilaments Determine Axonal Caliber in Myelinated Nerve Fibers // The Neuroscientist. 1995; 1 (2): 76-83. https:// doi.org/10.1177/107385849500100204

27. Sanders S. The thickness of the myelin sheaths of normal and regenerating peripheral nerve fibres. Proceedings of the Royal Society of London Series B - // Biological Sciences. 1948; 135 (880): 323-57. https:// doi.org/10.1098/ rspb.1948.0015

28. Rafuse V., Gordon T. Self-reinnervated cat medial gastrocnemius muscles. I. comparisons of the capacity for regenerating nerves to form enlarged motor units after extensive peripheral nerve injuries // Journal of Neurophysiology. 1996; 75 (1): 268-81. https:// doi.org/10.1152/jn.1996.75.1.268

29. Shefner J. Motor unit number estimation in human neurological diseases and animal models // Clinical Neurophysiology. 2001; 112 (6): 955-64. https:// doi.org/10.1016/s1388-2457(01)00520-x

30. Udina E., Ceballos D., Gold B., Navarro X. FK506 enhances reinnervation by regeneration and by collateral sprouting of peripheral nerve fibers // Experimental Neurology. 2003; 183 (1): 220-31. https://doi.org/10.1016/s0014-4886(03)00173-0

Отримано: 23.11.2019 


\title{
ВІДДАЛЕНІ РЕЗУЛЬТАТИ ТРАВМИ СІДНИЧОГО НЕРВА ТА ЙОГО ПРОТЕЗУВАННЯ КОНДУЇТОМ НА ОСНОВІ НИТКОВИДНИХ КРИСТАЛІВ КРЕМНІЮ: ГІСТОЛОГІЧНЕ ДОСЛІДЖЕННЯ ДИСТАЛЬНОГО ВІДРІЗКА НЕРВОВОГО СТОВБУРА ТА ЕЛЕКТРОНЕЙРОМІОГРАФІЧНЕ ДОСЛІДЖЕННЯ
}

\author{
Ліходієвський В.В., Корсак А.В., Скопець Д.С., Олефір С.С., Чухрай С.М., \\ Шамало С.М., Чайковський Ю.Б. \\ Національний медичний університет імені О.О. Богомольия, Киї, Украӥна \\ Legebrill@gmail.com
}

Актуальність. Тяжкі травми нервових стовбурів частіше спостерігаються у пацієнтів молодого віку та військовослужбовців і суттєво знижують якість життя. Такі пошкодження мають бути усунені із використанням різних методів нейропластики з використанням сучасних матеріалів.

Мета: встановлення впливу нитковидних кристалів кремнію на якість нервових волокон дистального відрізка травмованого периферійного нерва.

Матеріали та методи. Дослідження проведене на 40 щурах лінії Вістар: I група - псевдооперовані, II - моделювання 10 мм дефекта сідничого нерва та аутонейропластика. III - пластика аллогенною децелюлляризованою аортою та $4 \%$ карбоксиметилцеллюлозним гелем. IV - пластика аортою, гелем та орієнтованими нитковидними кристалами кремнію. Через 12 тижнів проводили стимуляційну голкову електронейроміографію литкового м'яза на боці ураження, для гістологічного дослідження забирали фрагменти дистального відрізку нерва. На міограмах визначали форми М-відповідей, їх амплітуди, затримку (латентність) сигналу. На зрізах підраховували діаметр нервового волокна та осьового циліндра, їх співвідношення, товщину мієлінової оболонки.

Результати. У щурів II та IV груп була більша якість нервових волокон в дистальному відрізку травмованого периферійного нерва. Про це свідчив більший діаметр нервових волокон у щурів цих груп у порівнянні із щурами III групи. Форма, амплітуда та латентність м-відповідей мали ознаки відновлення.

Висновки. Зроблений висновок про можливий прорегенераторний вплив нитковидних кристалів кремнію.

Ключові слова: травма периферійного нерва, протезування нерва, нитковидні кристали кремнію.

\section{ОТДАЛЕННЫЕ РЕЗУЛЬТАТЫ ТРАВМЫ СЕДАЛИЩНОГО НЕРВА И ЕГО ПРОТЕЗИРОВАНИЯ КОНДУИТОМ НА ОСНОВЕ НИТЕВИДНЫХ КРИСТАЛЛОВ КРЕМНИЯ: ГИСТОЛОГИЧЕСКОЕ ИССЛЕДОВАНИЕ ДИСТАЛЬНОГО ОТРЕЗКА НЕРВНОГО СТВОЛА И ЭЛЕКТРОНЕЙРОМИОГРАФИЧЕСКОЕ ИССЛЕДОВАНИЕ}

\author{
Лиходиевский В.В., Корсак А.В., Скопец Д.С., Олефир С.С., Чухрай С.Н., \\ Шамало С.Н., Чайковский Ю.Б. \\ Национальный медицинский университет имени А.А. Богомольйа, Киев, Украина \\ Legebrill@gmail.com
}

Актуальность. Тяжелые травмы нервных стволов чаще наблюдаются у пациентов молодого возраста и военнослужащих и существенно снижают качество жизни. Такие повреждения должны быть устранены путем разных методов нейропластики с использованием современных материалов.

Цель: установить воздействие нитевидных кристаллов кремния на качество нервных волокон дистального отрезка травмированного периферического нерва.

Материалы и методы. Исследование проведено на 40 крысах линии Вистар: I группа - псевдооперированные, II - моделирование 10 мм дефекта седалищного нерва и проведение аутонейропластики, III - пластика аллогенной децелюлляризованной аортой и 4\% карбоксиметилцеллюлозным гелем, IV - пластика аллогенной децелюлляризованой аортой, гелем и упорядоченными нитевидными кристаллами кремния. Через 12 недель проводили стимуляционную игольчатую электронейромиографию с регистрацией м-ответов с икроножной мышцы, измерением их амплитуды, задержки (латентности), после чего для гистологического исследования забирали фрагменты дистального отрезка нерва. На срезах подсчитывали диаметр нервных волокон, осевых цилиндром, их соотношение, толщину миелиновой оболочки.

Результаты. У крыс II и IV групп было большее качество нервных волокон в дистальном отрезке травмированного периферического нерва. Об этом свидетельствовал больший диаметр нервных волокон у крыс этих групп по ставнению с животными III группы. Форма м-ответа, амплитуда и латентность имели признаки восстановления.

Выводы. Сделан вывод о возможном прорегенераторном воздействии нитевидных кристаллов кремния.

Ключевые слова: травма периферического нерва, протезирование нерва, нитевидные кристаллы кремния. 